\title{
The Relationship between KBPR and Working Memory in Children with and without Specific Language Disorder: Phonological Loop and Episodic Buffer
}

\author{
Dongsun Yim ${ }^{\mathrm{a}}$, Hyunji Shin ${ }^{\mathrm{a}}$, Naeun Lim ${ }^{\mathrm{a}}$, Yeyoung Jung, Jimin Han ${ }^{\mathrm{a}}$, Yoonhee Yang \\ ${ }^{a}$ Department of Communication Disorder, Ewha Womans University, Seoul, Korea \\ ${ }^{b}$ The Special Education Research Institute, Ewha Womans University, Seoul, Korea
}

Correspondence: Dongsun Yim, PhD

Department of Communication Disorders, Ewha Womans University, 52 Ewhayeodae-gil, Seodaemun-gu, Seoul 03760, Korea

Tel: $+82-2-3277-6720$

Fax: $+82-2-3277-2122$

E-mail: sunyim@ewha.ac.kr

Received: October 15, 2020

Revised: November 6, 2020

Accepted: November 21, 2020

This work was supported by the Ministry of Science and ICT of the Republic of Korea and the National Research Foundation of Korea (NRF2019R1A2C1007488).

\begin{abstract}
Objectives: This study examined whether there is a significant relationship between Korean Brief Parent Report (KBPR) and Working Memory (phonological loop, episodic buffer); and investigated the significant predictor of children's language ability. Methods: A total of 52 children from 4 to 6 years old participated in this study composed of children with Specific Language Impairment (SLI), and typically developing (TD) children. Experimental tasks including KBPR, Non-Word Repetition (NWR), Word List Recall and a Symmetric-Asymmetric Matrix were used. One-way ANOVA, correlational, and multiple stepwise regression analysis were used. Results: 1) There was a significant difference between groups in section $B$ (Current abilities) and C (Behavior patterns and activity preferences). 2) There was a statistically significant difference in phonological loop and linguistic episodic buffer (EB). 3) The correlation between each section score of KBPR and working memory in the TD group showed consistent linguistic sentential order in the EB task with all the other sections except for section A. In the SLI group, section A had correlation with phonological loop, section $B$ had correlation with linguistic $E B$, and section $C$ had correlation with non-linguistic EB 4) The most significant predictor of the KBPR total score in the TD group was linguistic sentential order EB, and in the SLI group was phonological loop. Conclusion: Both the KBPR score and working memory task competency of the SLI and TD groups showed significant differences. In addition, the meaningful predictor in the total score of KBPR in each group respectively was NWR in the SLI group and linguistic sentential order EB in the TD group.
\end{abstract}

Keywords: Parent report, Parent questionnaires, Phonological loop, Episodic buffer, Working memory
부모 보고형 아동 언어 능력 평가도구(Korean Brief Parent Report, KBPR; Han \& Yim, 2018)는 부모를 통해 아동의 언어발달에 대한 정보를 간접적으로 얻을 수 있는 검사도구이다. 많은 선행연 구에서 부모 보고형 평가도구는 높은 타당도와 신뢰도를 가지며 어휘발달지체 선별도구로 사용하기에 적합하다고 보고된 바가 있 다(Bonifacci et al., 2016; May \& Williams, 2012; Paradis, Emmerzael, \& Duncan, 2010; Tuller, 2015). 한국어판 부모 보고형 평가도
구인 KBPR은 언어발달지체 아동에게 민감한 문항들로 구성되어 있어 부모가 아동의 언어 능력에 대해 또래와 비교하여 평가할 수 있으며, 아동에 대한 부모의 인식을 점수화한다는 점에서 기존의 부모설문 검사도구와는 다른 차별성을 가진다. KBPR은 (a) 초기 이 정표, (b) 현재 언어 능력, (c) 행동 패턴 및 활동 선호도, (d) 가족력 의 네 부분으로 아동의 과거 언어 및 신체 발달력과 현재 언어 수 준, 그리고 언어발달에 영향을 미칠 수 있는 다른 요인들을 검토할 
수 있는 문항으로 구성되어 있다. 부모 보고 평가 시 아동의 언어 능 력 점수에 영향을 미칠 수 있는 변인에는 가족과 아동의 특성, 과제 (task)와 절차의 영향(예: 과거 경험에 대한 회상이 아닌 현재 아동 의 행동에 대한 인식) 등이 있다는 것이 선행연구를 통해 밝혀진 바 있다(Diamond \& Squires, 1993). 이를 바탕으로 기존의 표준화된 아동 언어 능력 검사에 추가적으로 KBPR을 활용하면, 아동의 언 어 능력에 영향을 미치는 가족력, 아동의 발달사항, 행동 패턴 등을 총체적으로 이해할 수 있다. 국내 선행연구에서도 KBPR을 통해 부 모가 제공하는 아동의 정보는 타당하다고 보고하며, 설문 점수가 어휘발달지체 아동 부모의 특성을 반영한다는 점에서 선별도구로 의 가능성이 검증되었다(Han \& Yim, 2018).

한편, 작업기억(working memory)은 제한된 양의 정보를 일시적 으로 저장하고 유지하며 조작하는 인지처리 과정이다(Baddeley, 1986). 또한, 추론 및 문제해결, 언어 이해와 같은 복잡한 기능을 수 행할 때 중심적인 역할을 한다(Just \& Carpenter, 1992). 작업기억 은 네 가지 요소로 구성되어 있으며, 작업기억 내 흐름을 조정하는 중앙집행기(central executive), 청각-언어 정보를 다루는 음운루프 (phonological loop), 시 · 공간적 정보를 처리하는 시공간 스케치패 드(visuospatial sketchpad), 그리고 일화적 완충기(episodic buffer) 가 있다(Baddeley \& Wilson, 2002). 작업기억 중 음운루프는 언어 적 정보를 저장하며, 어휘 및 문법 능력 등 전반적인 언어 능력에 영 향을 준다(Yim \& Han, 2019). 이를 측정할 수 있는 방법에는 비단 어 따라말하기(non-word repetition)가 있다. 비단어 따라말하기 과제는 언어 및 사회적 사전 지식을 바탕으로 하는 기존의 검사도 구와는 달리 검사 중 아동의 수행 능력을 중점적으로 본다. 검사 시 아동이 비단어 따라말하기를 정확하게 수행하기 위해서는 적절한 지각, 언어처리, 기억 및 말 산출 능력이 필요하다(Hwang, 2015). 선 행연구에 따르면, 비단어 따라말하기 과제가 2-3세 아동들의 언어 능력을 민감하게 살펴볼 수 있기 때문에 아동의 초기 발달적 언어 능력을 진단할 수 있으며(Roy \& Chiat, 2004), 24-30개월 아동의 어 휘 능력과 무의미단어 따라말하기 수행 능력이 밀접한 관계가 있 음이 보고되었다(Stokes \& Klee, 2009). 나아가 비단어 따라말하기 수행 능력의 차이가 일반 아동과 단순언어장애 아동을 구별해줄 수 있음이 여러 연구를 통해 확인되었다. 비단어 따라말하기 과제 에서 일반 아동에 비해 단순언어장애 아동의 음운 단기기억 수행 력이 낮았으며(Gathercole \& Baddely, 1990), 학령전기 아동을 대상 으로 비단어 따라말하기 검사를 시행한 결과 단순언어장애 아동 과 일반 아동을 구별할 수 있는 유의미한 검사도구임이 밝혀졌다 (Dollaghan \& Campbell, 1998). 이와는 대조적으로 단순언어장애 아동과 일반 아동의 음운루프 용량에 유의한 차이가 없으며, 음운
루프가 아닌 중앙집행기의 결함으로 작업기억에 영향을 준다는 상 반된 연구결과도 있다(Baddeley, 1992; Gathercole \& Baddeley, 1993; Hong \& Yim, 2014).

작업기억에 새롭게 등장한 일화적 완충기(episodic buffer)는 음 운루프, 시공간 스케치패드, 장기기억으로부터 모은 정보를 덩이 (chunk)로 통합해 제한된 용량의 한계점을 보완한다. 언어적 덩이 는 단기기억의 용량 단위로 작은 단위가 모여 큰 단위를 형성하며, 문자(letter), 형태소(morpheme), 단어(word), 연어(collocation) 등 언어의 단위와 상응하게 된다(Ellis, 1996, 2003). 덩이짓기(chunking)는 사전 지식을 통해 단기기억 수준에서 처리 가능한 용량을 확장할 수 있는지 설명하며, 주어지는 정보들을 모아 하나의 단위 로 처리한다(Gobet et al., 2001; Mathy \& Feldman, 2012). 덩이짓기 를 활용하면 대화 상황에서 화자가 제공하는 자극을 청자가 항상 새롭게 인지하지 않고, 기존에 지닌 지식 내에서 감당할 수 있는 용 량만큼 사용하여 효율적으로 저장하고 처리할 수 있다(Hong, 2019). 이러한 덩이짓기는 정보처리 시 인지적 부하를 줄이는 효율적인 정 보처리 기제이며(Rönnberg, Rudner, Foo, \& Lunner, 2008), 시각 및 청각적 기억력을 기반으로 언어 학습 전반에 영향을 미친다고 알려져 있다(Casteel, 1988; Keenan, Bailet, \& Brown, 1984; KnightMcKenna, 2008; Stevens, 1981). 다수의 선행연구에서 단순언어장 애 아동들은 언어 능력의 결함뿐만 아니라 비언어적 정보처리용량 및 처리속도에서 어려움을 나타낸다고 보고한다(Johnston \& Weismer, 1983; Kohnert \& Windsor, 2004; Leonard et al., 2007; Windsor, Kohnert, Loxtercamp, \& Kan, 2008). 또한, 언어 능력이 지체된 아동은 언어정보를 덩이화하는 능력이 현저히 낮을 수 있음을 보 고한 여러 선행연구가 있으며, 특히 언어발달지체 아동의 경우 비언 어적인 과제가 수용 및 표현 어휘력을 예측해준다고 한다(Archibald \& Joanisse, 2009; Chun \& Yim, 2017; Hutchinson, Bavin, Efron, \& Sciberras, 2012; Yim, Kim, \& Yang, 2015). 따라서 본 연구는 덩이 짓기 능력을 비언어적 제시방식인 대칭-비대칭 매트릭스(matrix) 과제와 언어적 제시방식인 단어목록회상(word list recall) 과제를 통해 단순언어장애 아동 집단과 일반 아동 집단 간 일화적 완충기 의 수행도 차이를 알아보고자 한다. 언어와 작업기억과의 관계는 이미 많은 연구에서 증명되었으나, 부모 보고형 아동 언어 능력 평 가 결과와작업기억과의 관계에 대한 연구는 미비한 상태이므로 연 구의 필요성이 제기된다. 이에 본 연구에서는 궁극적으로 부모 보 고형 평가 결과에 영향을 미치는 작업기억 능력을 살펴보고자 한 다. 따라서 본 연구의 세부적인 연구 질문은 다음과 같다.

첫째, 일반 아동 집단과 단순언어장애 아동 집단 간 $\mathrm{KBPR}$ 영역 별 총점이 유의한 차이를 보이는가? 
둘째, 일반 아동 집단과 단순언어장애 아동 집단 간 작업기억(음 운루프, 일화적 완충기) 능력에 유의한 차이를 보이는가?

셋째, 일반 아동 집단과 단순언어장애 아동 집단 간 $\mathrm{KBPR}$ 의 영 역별 점수와작업기억(음운루프, 일화적 완충기) 능력 간 유의한 상 관관계를 보이는가?

넷째, 일반 아동 집단과 단순언어장애 아동 집단 간 $\mathrm{KBPR}$ 총점 을 가장 유의하게 예측할 수 있는 작업기억 과제(비단어 따라말하 기), 언어적 일화적 완충기(자유어순, 문장어순), 비언어적 일화적 완충기(대칭, 비대칭)는 무엇인가?

\section{연구방법}

\section{연구대상}

본 연구의 대상은 51-80개월(평균 63개월) 학령전기 단순언어장 애 아동 21 명 $(\mathrm{F}=9, \mathrm{M}=12)$, 일반 아동 31 명 $(\mathrm{F}=14, \mathrm{M}=17)$ 총 52 명 이참여하였다.

본 연구에 참여한 단순언어장애 아동은 (1) 부모 및 교사에 의해 지적 능력은 정상 범주에 속하지만, 언어 능력에 있어서는 부족함 을 나타내는 것으로 보고되었고, (2) 비언어성 인지검사인 카우프 만 아동 지능검사(K-ABC; Moon \& Byun, 2003) 결과 85점으로 -1 $\mathrm{SD}$ 이상이며, (3) 표준화 언어검사인 수용 및 표현어휘력 검사(Receptive Expressive Vocabulary Test, REVT; Kim, Hong, Kim, Jang, $\&$ Lee, 2009) 결과 수용 및 표현어휘 점수가 자신의 생활연령에 해 당하는 규준에서 -1.25 SD 미만이며, (4) 취학 전 아동의 수용 표현 언어 발달 척도(Preschool Receptive-Expressive Language Scale, PRES; Kim, Seong, \& Lee, 2003) 결과 수용 및 표현언어 점수가 모 두 $-1.25 \mathrm{SD}$ 미만이며, (5) 시각 및 청각 등의 감각장애, 행동 및 정서 장애, 신경학적 결함의 이력이 없는 아동을 대상으로 하였다.

또래 일반 아동들은 (1) 부모 또는 교사에 의해 인지, 언어, 그리 고 신체 능력이 정상으로 보고되고, (2) 비언어성 인지검사인 카우 프만 아동 지능검사(Kaufman Assessment Battery for Children, $\mathrm{K}-\mathrm{ABC}$; Moon \& Byun, 2003) 결과 85점으로 -1 SD 이상이며, (3) 수용 및 표현어휘력검사(Receptive Expressive Vocabulary Test, REVT; Kim et al., 2009) 결과 수용 및 표현언어 점수가 모두 정상 범주로 -1 SD 이상이며, (4) 취학 전 아동의 수용 표현 언어 발달 척 도(Preschool Receptive-Expressive Language Scale, PRES; Kim et al., 2003) 결과 수용 및 표현언어 점수가 모두 정상 범주로 -1 SD 이 상이며, (5) 시각 및 청각 등의 감각장애, 행동 및 정서 장애, 신경학 적 결함의 이력이 없는 아동을 대상으로 하였다.

일반 아동 및 단순언어장애 아동 집단의 구분이 잘 이루어졌는
Table 1. Participant's characteristics

\begin{tabular}{lccc}
\hline Variables & TD (N=31) & SLI (N=21) & $t$ \\
\hline Age (month) & $62.97(9.45)$ & $64.05(9.03)$ & -.412 \\
Nonverbal IO (standard score) & $107.94(11.35)$ & $103.19(10.10)$ & 1.545 \\
Receptive language $\left(\right.$ raw score) $^{b}$ & $58.71(10.58)$ & $45.67(17.69)$ & $3.032^{* *}$ \\
Expressive language $\left(\right.$ raw score) $^{b}$ & $66.26(10.10)$ & $53.29(16.51)$ & $3.217^{* *}$ \\
Receptive vocabulary $\left(\right.$ raw score) $^{c}$ & $46.97(9.97)$ & $38.00(12.14)$ & $2.915^{* *}$ \\
Expressive vocabulary $\left(\right.$ raw score) $^{c}$ & $46.90(8.41)$ & $36.71(12.92)$ & $3.205^{* *}$ \\
\hline
\end{tabular}

Values are presented as mean (SDs).

$\mathrm{TD}=$ Typically developing children; $\mathrm{SLI}=$ Children with specific language impairment. aKorean Kaufman Assessment Battery for Children (K-ABC; Moon \& Byun, 2003), 'Dreschool Receptive \& Expressive Language Scale (PRES; Kim, Sung, \& Lee, 2003), 'Receptive and Expressive Vocabulary Test (REVT; Kim et al., 2009). ${ }^{* *} p<.01$.

지 확인하기 위해 독립표본 $t$ 검정을 실시한 결과, 두 집단은 연령 및 비언어성 인지능력에 통계적으로 유의한 차이가 없었으며( $p>.05)$, 어휘(수용, 표현), 언어(수용, 표현) 4 가지 언어 표준화 검사 결과 TD 집단과 SLI 집단 간 차이가 통계적으로 유의하게 나타났다 $(p<.01)$. 본 연구에 참여한 아동들의 생활연령, 비언어성 지능, 수용 및 표현 어휘력 점수, 수용 및 표현언어 점수의 평균 및 표준편차를 Table 1 에 제시하였다.

\section{검사도구 및 절차}

본 연구에서는 학령전기 아동들을 대상으로 작업기억의 하위요 소인 음운루프와 일화적 완충기 능력을 측정하기 위한 연구도구를 선정하였다. 음운루프를 측정하기 위해 비단어 따라말하기 과제 (Non-Word Repetition)를 사용하였고, 일화적 완충기를 측정하기 위해 덩이짓기(Chunking)를 사용하였다. 또한, 부모 보고에 의한 아동 평가(KBPR)를 실시하였다.

\section{작업기억}

음운루프-비단어 따라말하기(Non-word Repetition) 과제

본 과제는 단어 유사성이 낮으면서 음소전이확률(phonotactic probability)이 높은 비단어 목록을 사용한 선행연구(Yim \& Han, 2019)의 과제를 사용하였다. 본 연구에서는 2음절(1단계)부터 6음 절(5단계)까지 순차적으로 제시되었으며, 각 단계는 3 문항씩 총 15 문장으로 구성되었다. 비단어는 음성 파일로 제시되었으며, 대상 아동에게 컴퓨터를 통해 음성을 듣는 즉시 바로 따라 말하도록 지 시하였다. 채점은 낱말 수준 채점방식을 적용하여 아동이 제시된 문항의 모든 음소를 올바르게 정반응하면 1점, 한 개의 음소라도 틀리게 반응하면 0 점으로 처리하여, 정반응한 문항의 수를 총점으 로 계산하였다. 
일화적 완충기-언어적 과제

일화적 완충기 중 언어적 능력을 측정하기 위해 Chun과 Yim (2017)의 연구에서 사용한 단어목록 회상 과제를 실시하였다. 검사 문항은 3 어절 단문, 5 어절 단문, 5 어절 접속복문, 7 어절 접속복문으 로 이루어진 총 26문항이며 이 중 문장어순(Chunking_Sentence order) 13문항, 자유어순(Chunking_Randomized order) 13문항으 로 구성하였다. 본 연구에서 문장어순이란 단어목록을 실제 문장 의 어순으로 배열하여 제시하는 조건으로, 조사가 없고 단음조로 제시되는 것을 제외하면 실제 문장과 동일하다. 반면, 자유어순은 문장 순에서 사용되는 낱말과 동일한 낱말을 사용하되 문장으로 여겨지지 않도록 이를 섞어 재배열한 문장이다.

평가는 두 블록으로 나누어 처음 블록에서 절반을 수행한 후 두 번째 블록에서 남은 절반의 문항을 따라말하기 놀이 식으로 수행 하였다. 동일 문장으로 만들어진 문장 순과 무선 순의 문항을 연이 어 접하여 학습효과가 일어나는 것을 통제하고, 아동의 피로감으 로 인한 수행도 저하를 예방하기 위해 문항을 두 블록으로 제시하 였다. 첫 블록에서 문장 순으로 제시되는 문항은 두 번째 블록에서 는 무선 순으로 제시되었다. 반대로 첫 블록에서 무선 순으로 제시 되었던 자극은 두 번째에서는 문장 순으로 제공되었다. 채점 방식 은 전체 문장을 정반응하면 아동 반응란에 + 를 기록하고, 부분적 으로라도 오반응할 경우 해당 문항의 반응을 모두 기록한다. 이 때 한 개의 낱말 당 1 점을 기준으로 아동이 해당 낱말을 바르게 회상 했을 경우 점수를 부여하며, 생략 또는 대치가 일어난 경우 감점한 다(예: 예쁜 그림 봐요(예쁜 그림 그려요) $\rightarrow 2$ 점). 순서를 바꿀 경우 에는 총점에서 도치의 횟수와 상관없이 문항당 1 점만 감점하였다 (예: 양말 신어요 아빠바지 입고(아빠 바지 입고 양말 신어요) $\rightarrow 4$ 점). 각 조건 별 예시는 Appendix 1과 같다.

\section{일화적 완충기-비언어적 과제}

비언어적 능력을 측정하기 위해 Chun과 Yim (2017)의 연구에서 사용한 과제를 실시하였다. $4 \times 4$ 로 구성된 총 16 개의 흰색 매트릭스 가 제시되며, 컴퓨터 화면에 0.5 초 간 파란색 매트릭스가 점등되었다 가 사라진다. 점등되는 불빛의 수는 3 개(1단계)에서 5 개(3단계)로 순 차적으로 점등되며, 대칭 조건과 비대칭 조건의 2 가지 조건으로 나 뉜다. 대상 아동들은 점등된 순서를 잘 기억했다가, 마지막 점등 후 정지화면이 제시된 후 순서대로 화면을 누르도록 하였다. 실험 전 연 습문항을 통해 아동이 충분히 숙지하였는지 확인 후 본 실험을 진 행하였다. 각 단계별로 8 문항이 제시되어 총 24 문항으로 구성되었으 며, 각 단계 내 대칭 조건과 비대칭 조건이 한 번씩 번갈아 가면서 제 시되었다. 대칭 조건과 비대칭 조건의 점등 순서는 Figure 1과 같다.

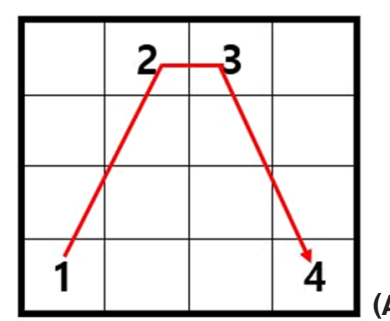

Symmetric

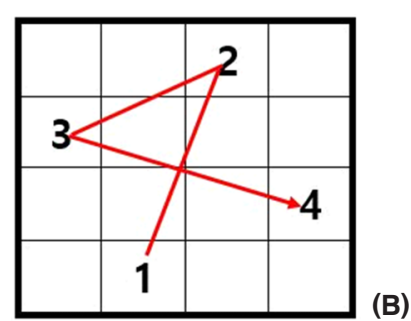

Asymmetric
Figure 1. Symmetric-asymmetric matrix. The picture on the left is an example for symmetric matrix and the picture on the right is an example for asymmetric matrix.

부모 보고형 아동 언어 능력 평가-KBPR (Korean Brief Parent Report) 과제

본 과제(KBPR; Han \& Yim, 2018)는 부모의 보고를 통해 아동의 언어 발달에 대한 정보를 얻을 수 있다는 장점이 있다. KBPR은 (a) 초기 이정표, (b) 현재 언어 능력, (c) 행동 패턴 및 활동 선호도, (d) 가족력의 네 영역으로 구성되어 있다. 각 영역별 문항 수는 다르며, 총 17 개 문항으로 이루어져 있다. 첫 번째 (a) 초기 이정표는 총 4 문 항으로, 총점은 18 점이며, 걸음마 시기, 첫 낱말 시기 등에 따라 점 수를 차등으로 계산한다. 두 번째 (b) 현재 언어 능력은 총 5 문항, 15 점이며, 아동의 표현 능력, 조음 능력, 의사소통 능력, 문장 구성 능 력, 현 언어 수준에 대한 가족의 만족도를 묻는 문항으로 구성되어 있다. 세 번째 (c) 행동 패턴 및 활동 선호도는 총 6문항, 총점은 18 점 이며, 책 읽기 선호도, 문해 능력, 선호하는 활동 등의 문항이 포함 된다. 마지막 (d) 가족력은 총 2문항, 총점은 9점이며, 가족 구성원 의 교육 수준과 가족 및 친척 중 학습과 언어에 어려움이 있는지 평 가할 수 있는 문항으로 구성하였다. KBPR의 영역별 점수는 각 영 역의 문항을 모두 더해 산출하였으며, 총점은 각 영역의 총점들을 모두 합산하여 산출하였다. 본 평가도구의 내용은 Appendix 2와 같다.

\section{자료분석 및 결과처리}

일반 아동 집단과 단순언어장애 아동 집단간 $\mathrm{KBPR}$ 영역별 점수 와 총 점수를 비교하기 위해 일원분산분석(one-way ANOVA)을 사용하였다. 또한 집단 간 집행기능(음운루프, 일화적 완충기, 시공 간 스케치패드) 과제 수행도에 차이를 알아보기 위해 일원분산분 석(one-way ANOVA) 및 반복측정분산분석(Repeated measures $\mathrm{ANOVA})$ 을 사용하였다. 집단 간 $\mathrm{KBPR}$ 의 각 영역별 점수 결과와 집행기능 간 상관관계를 알아보기 위해 피어슨 적률상관계수(Pearson's product moment correlation coefficient)를 산출하였다. 음운 루프, 언어적 일화적 완충기와 비언어적 일화적 완충기 중 일반 아 
동 집단과 단순언어장애 아동 집단 각각에서 $\mathrm{KBPR}$ 총점에 유의한 예측요인을 찾기 위해 다중 단계적 회귀분석(Multiple stepwise regression)을 사용하였다. 본 연구의 모든 통계분석은 SPSS ver. 25 (SPSS Inc., Chicago, IL, USA)를 사용하였다.

\section{연구결과}

\section{일반 아동 집단과 단순언어장애 아동 집단 간 KBPR 영역별 점수 및 총 점수 비교}

일원분산분석(one-way ANOVA)을 통해 집단 간 KBPR 영역별 점수 및 총 점수를 비교하여 본 결과, $\mathrm{KBPRb}$ (현재 언어 수준), $\mathrm{KB}$ $\mathrm{PRc}$ (행동 패턴 및 활동 선호도), KBPR_total (총점)에서 두 집단 간 유의한 차이를 보였다 $(p<.05$ ). 즉, $\mathrm{KBPRb}$ (현재 언어 수준)에서 $\mathrm{TD}$ 집단의 평균은 $11.06(\mathrm{SD}=3.21)$ 점, SLI 집단의 평균은 9.02 $(\mathrm{SD}=3.05)$ 점으로 $\mathrm{TD}$ 집단 비해 $\mathrm{SLI}$ 집단의 점수가 유의하게 낮았 다 $\left(F_{(1,50)}=5.255, p=.026\right) . \mathrm{KBPRc}$ (행동 패턴 및 활동 선호도)에서 $\mathrm{TD}$ 집단의 평균은 $12.74(\mathrm{SD}=2.80)$ 점, $\mathrm{SLI}$ 집단의 평균은 10.86 $(\mathrm{SD}=2.89)$ 점으로 $\mathrm{TD}$ 집단에 비해 SLI 집단의 점수가 유의하게 낮 았다 $\left(F_{(1,50)}=5.525, p=.023\right)$. KBPR_total (총점)에서도 두 집단의 차이는 유의하였으며, $\mathrm{TD}$ 집단의 평균은 $47.65(\mathrm{SD}=8.69)$ 점, $\mathrm{SLI}$ 집단의 평균은 $41.81(\mathrm{SD}=8.25)$ 점이었다 $\left(F_{(1,50)}=5.878, p=.019\right)$. $\mathrm{KBPRa}$ (초기 이정표)나 KBPRd (가족력)에서는 두 집단 간 유의한 차이가 없었다( $p>$.05). 이에 대한 세부 결과를 Table 2에 제시하였다.

\section{일반 아동 집단과 단순언어장애 아동 집단 간 작업기억(음운루프, 일화적 완충기, 시공간 스케치패드) 과제 수행도의 차이}

NWR (비단어 따라말하기) 문항 점수에서 집단 간 유의한 차이 가 있었다 $\left(F_{(1,50)}=5.237, p=.026\right)$. 즉, 일반 아동 집단 $(\mathrm{M}=9.03$,

Table 2. KBPR scores by subgroups

\begin{tabular}{lrrl}
\hline Variables & TD $(\mathrm{N}=31)$ & $\mathrm{SLI}(\mathrm{N}=21)$ & \multicolumn{1}{c}{$F$} \\
\hline KBPRa & $15.32(3.94)$ & $14.05(4.75)$ & 1.111 \\
KBPRb & $11.06(3.21)$ & $9.02(3.05)$ & $5.255^{*}$ \\
KBPRc & $12.74(2.80)$ & $10.86(2.89)$ & $5.525^{*}$ \\
KBPRd & $8.52(1.36)$ & $7.86(2.01)$ & 1.994 \\
KBPR total & $47.65(8.69)$ & $41.81(8.25)$ & $5.878^{*}$ \\
\hline
\end{tabular}

Values are presented as mean (SDs).

$\mathrm{TD}=$ Typically developing children; SLI=Children with specific language impairment; $\mathrm{KBPR}=$ Korean Brief Parent Report; $\mathrm{KBPRa}=$ Early Milestones, $\mathrm{KBPRb}=$ Current Language Abilities; $K B P R c=$ Behavior Patterns and Activity Preferences; $K B P R d=$ Family History.

${ }^{*} p<.05$.
$\mathrm{SD}=.498)$ 에 비해 단순언어장애 아동 집단 $(\mathrm{M}=7.24, \mathrm{SD}=.605)$ 이 유의하게 낮은 수행을 보였다.

언어적 일화적 완충기 과제 수행에서도 문장어순 조건에서 두 집단 간 유의한 차이가 있었다 $\left(F_{(1,50)}=4.654, p=.036\right)$. 즉, 일반 아 동 집단에 비해 단순언어장애 아동 집단이 유의하게 낮은 수행을 보였다. 또한, 세부 조건에 따른 집단 간 수행 차이를 살펴보았을 때, 5 어절 조건 $\left(F_{(1,50)}=4.452, p=.040\right)$ 과 7 어절 조건 $\left(F_{(1,50)}=6.209, p=\right.$ .016)에서 집단 간 차이가 유의하였다. 그러나, 비언어적 일화적 완충 기 과제 수행에서 두 집단 간 유의한 차이가 없었으며 $\left(F_{(1,50)}=.027\right.$, $p=.871)$, 세부 조건에 따른 집단 간 수행 차이 역시 유의하지 않았 다( $p>.05)$. 즉, 일반 아동 집단에 비해 단순언어장애 아동 집단 간 통계적으로 유의한 차이는 없었다. 이에 대한 세부 결과를 Table 3 , Figure 2에 제시하였다.

\section{일반 아동 집단과 단순언어장애 아동 집단 간 $\mathrm{KBPR}$ 의 각 영역별 점수 결과와 작업기억 간 상관관계}

$\mathrm{KBPR}$ 의 네 영역인 (a) 초기 이정표, (b) 현재 언어 능력, (c) 행동 패턴 및 활동 선호도, (d) 가족력의 영역별 점수 결과와작업기억 간 의 상관관계를 알아보고자 한다.

일반 아동 집단의 경우 KBPR의 (a)인 초기 이정표와작업기억 간

Table 3. Working Memory (phonological loop, linguistic episodic buffer, nonlinguistic episodic buffer) scores by subgroups

\begin{tabular}{lccc}
\hline Variables & TD (N=31) & SLI (N=21) & $F$ \\
\hline NWR & $9.03(.498)$ & $7.24(.605)$ & $5.237^{*}$ \\
L_EB & & & $4.654^{*}$ \\
(S) 3 words & $91.94(3.00)$ & $85.71(3.65)$ & \\
(S) 5 words & $74.52(4.13)$ & $60.79(5.02)$ & \\
(S) 7 words & $68.05(4.23)$ & $51.47(5.14)$ & \\
(F) 3 words & $84.95(3.54)$ & $75.00(4.30)$ & \\
(F) 5 words & $55.05(3.55)$ & $44.92(4.31)$ & \\
(F) 7 words & $37.94(3.53)$ & $33.79(4.29)$ & \\
NL_EB & & & \\
(S) span 3 & $51.61(6.69)$ & $48.81(8.12)$ & .027 \\
(S) span 4 & $35.48(7.05)$ & $30.95(8.57)$ & \\
(S) span 5 & $12.90(3.96)$ & $10.71(4.81)$ & \\
(A) span 3 & $34.68(6.43)$ & $38.10(7.82)$ & \\
(A) span 4 & $12.10(4.44)$ & $11.91(5.40)$ & \\
(A) span 5 & $2.42(1.62)$ & $2.38(1.97)$ & \\
\hline
\end{tabular}

Values are presented as mean (SEs).

$\mathrm{TD}=$ Typically developing children; $S \mathrm{~L}=$ = Children with specific language impairment; NWR= Nonword Repetition; L_EB $(S)=$ Linguistic Episodic Buffer (sentence order); L_EB $(R)=$ Linguistic Episodic Buffer (randomized order); NL_EB $(S)=$ Nonlinguistic Episodic Buffer (symmetric); NL_EB (A) = Nonlinguistic Episodic Buffer (asymmetric). ${ }^{*} p<.05$. 

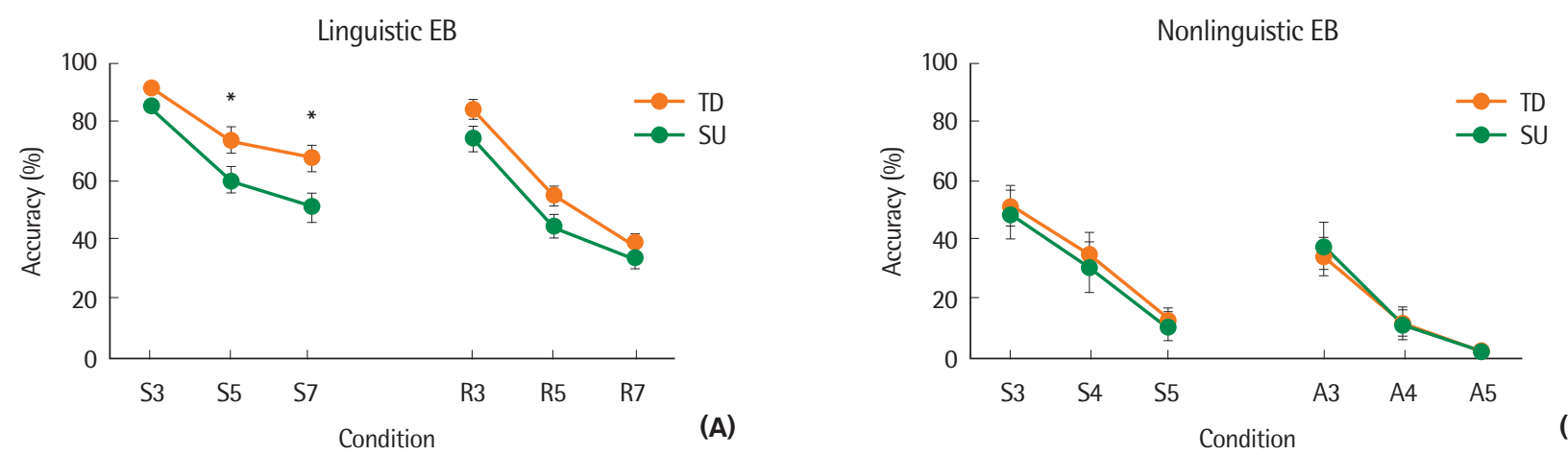

(B)

Figure 2. Linguistic (a) and nonlinguistic (b) episodic buffer task competency (\%) in both groups. Both graph (a) and (b) show the linguistic and nonlinguistic episodic buffer task competency $(\%)$ depending on the length of the word segment $(3,5,7$ or 3, 4, 5) and sentence order (S), randomized order (R).

$\mathrm{EB}=$ Episodic Buffer; TD= Typically Developing; SLI = Specific Language Impairment.

Table 4. Correlation matrix in TD group

\begin{tabular}{lccccc}
\hline Variables & NWR & L_EB $(S)$ & L_EB (R) & NL_EB (S) & NL_EB (A) \\
\hline KBPRa & .002 & .272 & .229 & .340 & .292 \\
KBPRb & .018 & $.507^{* *}$ & $.476^{* *}$ & .208 & .310 \\
KBPRc & -.187 & $.621^{* * *}$ & $.543^{* *}$ & $.398^{*}$ & $.429^{*}$ \\
KBPRd & -.313 & $.387^{*}$ & .195 & .287 & .210 \\
\hline
\end{tabular}

$\mathrm{KBPR}=$ Korean Brief Parent Report; $\mathrm{KBPRa}=$ Early Milestones; $\mathrm{KBPRb}=$ Current Language Abilities; KBPRC=Behavior Patterns and Activity Preferences; $K B P R d=$ Family History; NWR= Nonword Repetition; L_EB (S)=Linguistic Episodic Buffer (sentence order); L_EB (R)=Linguistic Episodic Buffer (randomized order); NL_EB $(S)=$ Nonlinguistic Episodic Buffer (symmetric); NL_EB (A)=Nonlinguistic Episodic Buffer (asymmetric).

${ }^{*} p<.05,{ }^{* *} p<.01,{ }^{* * *} p<.001$

상관이 유의하지 않았다( $p>.05)$. (b)의 현재 언어 능력은 언어적 일 화적 완충기 문장어순 $(r=.507, p=.004)$, 자유어순 $(r=.476, p=.007)$ 과 상관이 유의하였다. (c)의 행동 패턴 및 활동 선호도는 언어적 일 화적 완충기 문장어순 $(r=.621, p=.000)$, 자유어순 $(r=.543, p=.002)$, 비언어적 일화적 완충기 대칭 $(r=.398, p=.027)$, 비대칭 $(r=.429$, $p=.016)$ 과상관이 유의하였다. (d)의 가족력은 언어적 일화적 완충 기 문장어순 $(r=.387, p=.032)$ 과 유의한 상관관계를 보였다. 결과적 으로 일반 아동 집단의 KBPR 각 영역별 점수와 작업기억 간의 상 관관계를 보았을 때, 언어적 일화적 완충기 문장어순이 (a) 초기 이 정표를 제외하고 일관되게 유의한 상관관계가 나타나는 요인이다.

단순언어장애 아동 집단의 경우 $\mathrm{KBPR}$ 의 (a)인 초기 이정표와 유 의한 상관이 있는 요인은 비단어 따라말하기로 나타났다 $(\mathrm{r}=.626$, $p=.002)$. (b)의 현재 언어 능력과 유의한 상관이 있는 요인은 언어 적 일화적 완충기 문장어순 $(r=.446, p=.043)$ 이었다. (c)의 행동 패 턴 및 활동 선호도는 비언어적 일화적 완충기 대칭 $(r=.597, p=.004)$, 비대칭 $(r=.658, p=.001)$ 과 유의한 상관이 있었다. (d)의 가족력은 작업기억과 유의한 상관이 없었다 $(p>.05)$. 즉, 단순언어장애 아동
Table 5. Correlation matrix in SLI group

\begin{tabular}{lccccc}
\hline Variables & NWR & L_EB (S) & L_EB (R) & NL_EB (S) & NL_EB (A) \\
\hline KBPRa & $.626^{* *}$ & -.057 & -.020 & .079 & .037 \\
KBPRb & .419 & $.466^{*}$ & .428 & .296 & .183 \\
KBPRc & .242 & .345 & .328 & $.597^{* *}$ & $.658^{* *}$ \\
KBPRd & -.299 & .362 & .334 & .322 & .201 \\
\hline
\end{tabular}

$\mathrm{KBPR}=$ Korean Brief Parent Report; $\mathrm{KBPRa}=$ Early Milestones; $\mathrm{KBPRb}=$ Current Language Abilities; KBPRc=Behavior Patterns and Activity Preferences; KBPRd= Family History; NWR= Nonword Repetition; L_EB $(S)=$ Linguistic Episodic Buffer (sentence order); L_EB (R)=Linguistic Episodic Buffer (randomized order); NL_EB $(S)=$ Nonlinguistic Episodic Buffer (symmetric); NL_EB $(A)=$ Nonlinguistic Episodic Buffer (asymmetric).

${ }^{*} p<.05,{ }^{* *} p<.01$.

집단의 경우 $\mathrm{KBPR}$ 각 영역별 점수와작업기억 간의 상관관계를 보 았을 때, (a)는 음운루프, (b)는 언어적 일화적 완충기, (c)는 비언어 적 일화적 완충기와 유의한 상관이 있었다. 이에 대한 세부적인 결 과를 Tables 4,5 에 제시하였다.

\section{작업기억(음운루프, 언어 및 비언어적 일화적 완충기) 중 일반 아동 집단과 단순언어장애 아동 집단 각각에서 $\mathrm{KBPR}$ 총점에 유의한 예측요인}

일반 아동 집단과 단순언어장애 아동 집단의 $\mathrm{KBPR}$ 총점에 가장 유의한 예측요인을 알아보기 위해 다중회귀분석(Multiple stepwise regression)을 사용하였다. 일반 아동 집단의 KBPR 총점에 대해 비 단어 따라말하기(NWR), 언어적 일화적 완충기(L_EB_S, 문장어 순), 언어적 일화적 완충기(L_EB_R, 자유어순), 비언어적 일화적 완충기(NL_EB_S, 대칭), 비언어적 일화적 완충기(NL_EB_A, 비 대칭) 5 개 요인 중 가장 유의한 예측요인은 언어적 일화적 완충기 (L_EB_S, 문장어순)로 $32.7 \%$ 의 설명력을 보였다 $\left(r^{2}=.327, p=.001\right)$. 단순언어장애 아동 집단의 KBPR 총점에 대해 비단어 따라말하 
기(NWR), 언어적 일화적 완충기(L_EB_S, 문장어순), 언어적 일화 적 완충기 $\left(\mathrm{L} \_\mathrm{EB} \_\mathrm{R}\right.$, 자유어순 $)$, 비언어적 일화적 완충기 $\left(\mathrm{NL} \_\mathrm{EB}\right.$ $\mathrm{S}$, 대칭), 비언어적 일화적 완충기(NL_EB_A, 비대칭) 5 개 요인 중 가장 유의한 예측요인은 비단어 따라말하기(NWR)이며 $28.0 \%$ 의 설명력을 지닌다 $\left(r^{2}=.280, p=.014\right)$. 또한, 비단어 따라말하기(NWR) 는 언어적 일화적 완충기(L_EB_R, 자유어순)와 함께 $51.3 \%$ 의 설 명력을 지니는 예측요인인 것으로 나타난다 $\left(r^{2}=.513, p=.002\right)$.

\section{논의 및 결론}

본 연구는 단순언어장애 아동 집단과 일반 아동 집단의 KBPR 영역별 점수 및 작업기억 능력 간 차이가 있는 지 확인하고, $\mathrm{KBPR}$ 과 작업기억 간 유의한 상관관계가 있는지, $\mathrm{KBPR}$ 을 유의하게 예측 할 수 있는 작업기억은 어떠한 것인지 알아보고자 하였다.

먼저, 일반 아동 집단과 단순언어장애 아동 집단 간 $\mathrm{KBPR}$ 영역 별 점수 및 총 점수를 비교하였을 때, 각 영역에 따라 상이한 결과 를 보였다. (b) 현재 언어 수준 영역에서 일반 아동 집단과 단순언어 장애 아동 집단 간 $\mathrm{KBPR}$ 영역별 총 점수를 비교하였을 때 유의한 차이가 나타났다. 이를 통해 단순언어장애 아동의 부모가 현재 아 동의 언어에 대해 인식하고 있다는 것으로 해석할 수 있다. 또한, (c) 행동 패턴 및 활동 선호도 영역에서는 일반 아동 집단과 단순언어 장애 아동 집단 간 $\mathrm{KBPR}$ 영역별 총 점수를 비교하였을 때 유의한 차이가 나타났는데 이는 캐나다, 호주, 이탈리아에서 실시된 선행 연구의 결과와 일치한다(Boniffaci et al., 2016; May \& Williams, 2012; Paradis et al., 2010). 즉, 단순언어장애 아동의 부모가 또래 아 동과 비교한 아동의 읽기 및 쓰기 능력, 학습 효율성, 의사소통 시 아동의 성향에 대해 일반 아동과 다르게 인식했음을 의미한다.

반면, (a) 초기 이정표 및 (d) 가족력의 경우 집단 간 유의미한 차 이가 없었다. (a) 초기 이정표는 부모가 자신의 아이와 또래와의 객 관적 비교가 어려웠거나, 아동의 초기 이정표 사건이 언제 발생하 였는지에 대해 정확하게 기억하는데 어려움을 겪었을 수 있다. Diamond와 Squires (1993)는 부모들이 과거 경험에 대한 회상이 요구 되는 경우 현재 아동의 행동을 인식하는 문항에 대해 상대적으로 부정확하게 회상할 수 있음을 언급한 바 있다. 따라서 과거 경험에 대한 회상이 요구되는 (a) 초기 이정표에서 본 연구의 경우 유의미 한 결과가 나오지 않았음을 예측할 수 있다. 또한, 이와 관련하여 일 부 과거 회상이 요구될 수 있는 (d) 가족력에 대해서도 본 연구에서 는 민감하게 반응하지 않았던 것으로 해석할 수 있다.

다음으로 일반 아동 집단과 단순언어장애 아동 집단 간 작업기 억(음운루프, 일화적 완충기) 과제 수행도에는 작업기억의 음운루
프 ‘비단어 따라말하기 과제’의 문항 점수에서 집단 간 수행력에 유 의한 차이가 있었다. 즉, 일반 아동 집단에 비해 단순언어장애 아동 집단이 유의하게 낮은 수행을 보였는데, 이는 비단어 따라말하기 가 언어장애 아동을 선별하는 검사도구로 사용할 수 있다는 선행 연구와 일치하는 결과이다(Dollaghan \& Campbell, 1998; Gathercole \& Baddely, 1990; Hwang, 2015; Oh \& Yim, 2013; Roy \& Chiat, 2004; Stokes \& Klee, 2009). 또한, 단순언어장애 아동 집단과 일반 아동 집단은 언어적 일화적 완충기 과제에서는 유의한 차이가 있었 으나, 비언어적 일화적 완충기 과제에서는 집단 간 통계적으로 유의 한 차이가 없었다. 다수의 선행연구에 따르면, 단순언어장애 아동 은 시공간 영역보다 청각적 영역에서 아동의 처리 과정에 어려움이 있다고 보고한다(Vugs, Cuperus, Hendriks, \& Verhoeven, 2013, Yim, Yang, \& Kim, 2015). 언어적 일화적 완충기 과제인 단어목록 회상 과제 수행은 청각적 양식만 사용하므로, 단순언어장애 아동 이 일반 아동에 비해 어려움을 보였을 것이다. 반면, 비언어적 일화 적 완충기 과제인 매트릭스의 경우, 덩이짓기 및 장기기억 인출이 시각적 양상보다는 구어적 양상에만 있을 가능성이 존재하여 두 집단 간 통계적으로 유의한 차이가 나지 않았다고 해석할 수 있다 (Chun \& Yim, 2017).

다음으로 일반 아동 집단과 단순언어장애 아동 집단의 $\mathrm{KBPR}$ 각 영역별 점수와 상관관계를 보이는 작업기억(음운루프, 일화적 완 충기)은 영역마다 상이한 결과를 보였다.

$\mathrm{KBPR}$ (a) 초기 이정표 영역에서 단순언어장애 아동 집단은 비단 어 따라말하기 과제와 유의한 상관을 보였다. 음운루프를 사용한 기술인 음운 기억은 언어발달 초기부터 형성하여 어린 아동의 언 어발달에 중요한 영향을 미치며, 음운 기억과 기존의 어휘 지식은 새로운 단어를 학습하는데 유기적으로 연결되어 중요한 역할을 한 다(Baddeley, Gathercole, \& Papagno, 1998). 또한 음운루프는 어휘 학습, 문법 습득 능력 등 전반적인 언어 능력에 영향을 주는 처리기 제로 보고하였다(Yim \& Han, 2019). 이를 측정할 수 있는 비단어 따라말하기는 청각적 기억과 음운 조합, 말 산출 등의 능력을 요구 하는 과제이다. 부족한 음운 기억 및 산출 능력은 새로운 어휘를 학 습할 때 어려움을 보이며, 음운루프는 새롭게 접하는 음운의 조합 을 할 때 민감성과 수용 가능성을 보여주므로, 언어 및 어휘 습득 초기 단계에서 중요한 기제가 된다(Gathercole, 2006; Montgomery \& Windsor, 2007). 또한, 아동의 언어 능력은 유아기의 신경계, 생 물학적 특징들과의 상호작용에 의해 발달하는데(Cho et al., 2008), (a) 초기 이정표 영역에는 아동의 신체 및 언어 발달과 직접적인 관 련이 있는 문항이 포함되어 있다. 이러한 아동의 전반적 발달 사항 들은 추후 학령기 언어발달의 기초가 되므로 중요한 지표가 된다 
(Cho et al., 2008). 다수의 선행연구에서도 (a) 초기 이정표 영역은 단순언어장애 아동과 일반 아동을 구별할 수 있는 강력한 요인이 라고 언급하였다(Bonnifaci et al., 2016; Karimijavan et al., 2019). 따라서 단순언어장애 아동 집단의 (a) 초기 이정표 영역을 확인하 는 것이 중요하다고 해석할수 있다.

$\mathrm{KBPR}$ (b) 현재 언어 능력 영역에서 일반 아동 집단에서 언어적 일화적 완충기의 문장어순, 자유어순 과제에서 유의한 상관을 보 였다. 단순언어장애 아동 집단은 언어적 일화적 완충기의 문장어 순 과제에서 유의한 상관을 보였다. 현재 언어 능력과 유의한 상관 관계를 보이는 작업기억은 두 집단 모두 언어적 일화적 완충기의 문장어순 과제였다. 언어 사용자는 언어적 일화적 완충기를 통해 음소 및 음절부터 다양한 수준의 덩이를 저장하고 이에 의존하여 언어 이해 및 산출에 사용한다(Arnon \& Snider, 2010; Bannard \& Matthews, 2008; Janssen \& Barber, 2012). 선행연구에 따르면, 언어 적 일화적 완충기 능력은 아동의 음운 지식 및 어휘 학습 능력과 관 련이 있으며, 개인의 언어지식에 따라 다르게 나타날 수 있고, 이를 효율적으로 사용할 수 있을 때 언어 사용자들에게 효과적인 전략 일 수 있다(Jones, Gobet, Freudenthal, Watson, \& Pine, 2014; Nation, 2001). 따라서, 두 집단 모두에게서 현재 언어 능력과 언어적 일화적 완충기 간 유의한 상관이 나타난 것으로 보인다.

$\mathrm{KBPR}$ (c) 행동 패턴 및 활동 선호도 영역에서 일반 아동 집단은 언어적 일화적 완충기(문장어순 및 자유어순) 과제, 비언어적 일화 적 완충기(대칭 및 비대칭) 과제에서 모두 유의한 상관을 보였다. 반 면, 단순언어장애 아동 집단은 비언어적 일화적 완충기(대칭 및 비 대칭) 과제에서만 유의한 상관을 보였다. 이는 일반 아동 집단의 경 우 학습 및 활동 시 언어 및 비언어 일화적 완충기 과제 수행력과 모 두 긴밀한 연관성을 지니는 반면, 단순언어장애 아동 집단에서는 내재하는 언어적 어려움으로 인해 언어적 일화적 완충기보다는 비 언어적 일화적 완충기 과제 수행만이 유의한 연관성을 지닌 것으 로 해석할 수 있다.

$\mathrm{KBPR}$ 의 (d) 가족력 영역에서 일반 아동 집단은 언어적 일화적 완충기의 문장조건과 유의한 상관을 보이는 것으로 나타났다. 선행 연구에 따르면, 지금까지 알려진 단순언어장애 아동의 유전 인자로 는 (d) 가족력 영역이 묻는 질문과 같이 가족력과 부모의 교육 수준 등으로 알려져 있다(Bishop, 1997; Cheuck \& Wong, 2005; Cheuck,

\section{Wong, \& Leung, 2005; Stanton-Chapman, Chapman, Bainbridge,} \& Scott, 2002; Tomblin, Smith, \& Zhang, 1997). 이와 같이 단순언 어장애가 있는 아동의 가족 중에서 언어나 학습 장애 발생률이 더 높은 것으로 보고되었다(Chung, 2008). 따라서 유전적 요인에 따 라 언어발달에 지연을 보일 가능성이 있는 아동의 경우, 어휘, 구문,
문법과 같은 언어 능력을 기초로 만들어지는 ‘덩이짓기’ 능력 또한 비교적 낮은 수행력을 보일 수 있음을 예측할 수 있다(Baddeley \& Wilson, 2002; Polišenská, Chiat, \& Roy, 2015). 이러한 선행연구를 근거로 본 연구에서는 단순언어장애 아동의 언어 능력이 가족력과 유의한 상관관계가 존재할 것으로 예측하였다. 그러나 연구 결과 에 의하면 가족력과 유의한 상관관계를 보인 요인은 일반 아동의 언어적 일화적 완충기 과제였다. 일반 아동의 경우 (b) 현재 언어 능 력, (c) 행동 패턴 및 활동 선호도 영역에서도 언어적 일화적 완충기 와 비교적 일관된 상관관계를 보였기 때문에 (d) 가족력 영역에서 도 유의한 관계를 나타냈을 것이라고 예측할 수 있다. 단순언어장 애 아동의 경우 부모 또는 조부모 세대에서 언어발달상의 취약함 을 경험했을 가능성이 존재함에도 불구하고, 그것을 미처 인지하 지 못하고 성장했거나 과거 경험에 대한 회상이 부정확할 가능성 도 존재한다. 추후 가족력을 보다 정확하게 측정할 수 있는 문항을 보완하거나 본 연구에서 사용한 과제 외에 언어적인 요소를 볼 수 있는 다양한 과제를 사용하여 단순언어장애 아동과 가족력과의 상관관계를 살펴볼 필요가 있다.

마지막으로, 일반 아동 집단과 단순언어장애아동 집단에서 $\mathrm{KBPR}$ 총점에 가장 유의한 작업기억 예측요인을 살펴보고자 했다. 본 연 구에서 일반 아동 집단 내 $\mathrm{KBPR}$ 의 총 점수와 유의한 상관관계를 보이는 요인은 문장조건의 언어적 일화적 완충기 과제였다. $\mathrm{KBPR}$ 의 전체적 영역들을 살펴보면 아동의 운동 기능 및 초기 언어 능력, 현재 언어 능력, 행동 패턴 및 활동 선호도 및 가족력으로 구성되어 있다. 따라서 이러한 $\mathrm{KBPR}$ 영역들의 총 점수는 아동의 언어 능력 대한 부모의 총체적 인식을 반영하는 것으로 해석해 볼 수 있다. 일 반 아동의 경우 문장어순 과제에서 아동에게 제공되는 자극이 친 숙하거나 통용되는 어순을 따를 때 정보처리에 도움을 받을 수 있 어 언어적 일화적 완충기 과제 중 문장어순에서 높은 수행도를 보 인다고 알려져 있다(Yang, Park, Hong, Lee, \& Yim, 2019). 따라서 본 연구에서도 일반 아동 집단에서 언어적 일화적 완충기(문장어 순) 수행이 KBPR 총점에 유의한 예측요인이 될 수 있었을 것이라 고 추측해 볼 수 있다. 비단어 따라말하기 과제는 음운 기억, 청각 정보 재인, 음운 표상, 말 운동, 말소리 산출 능력 등을 살펴볼 수 있 어 아동의 말 언어발달상 문제를 선별해내기 위한 지표로 유용하 게 사용된다(Chiat \& Roy, 2007; Lee, 2010; Lee \& Sim, 2003; Shriberg et al., 2009; Stark \& Blackwell, 1997). 따라서 단순언어장애 아 동 집단의 경우, 아동 집단 내 $\mathrm{KBPR}$ 의 총점과 가장 유의한 상관관 계를 보이는 요인이 비단어 따라말하기 과제였음을 알 수 있다.

정리하자면, 본 연구는 단순언어장애 아동 집단과 일반 아동 집 단의 작업기억(음운루프, 일화적 완충기) 능력을 살펴보고, 두 집 
단 간 $\mathrm{KBPR}$ 영역별 하위 점수 및 총 점수, 작업기억에 유의한 차이 가 있는지, KBPR 각 영역과 유의한 상관을 보이는 작업기억이 무엇 인지, KBPR 총 점수를 예측할 수 있는 작업기억은 무엇인지 살펴 보고자 하였다.

후속연구에서는 본 연구에서 실시하지 않은 더욱 다양한 작업기 억의 과제를 시행하여 KBPR과의 연관성을 살펴봄으로써 작업기 억과 KBPR과의 폭넓은 상관관계를 볼 수 있기를 제안한다. 더불어 $\mathrm{KBPR}$ 의 영역 중 (c) 행동 패턴 및 활동 선호도의 경우, 본 연구 결 과에서 KBPR 영역과 유의한 상관을 보인 작업기억 과제를 바탕으 로 하는 문항을 포함하여 추후 KBPR의 판별력을 알아볼 것을 제 언한다. 예를 들어, 언어 및 비언어적 일화적 완충기 과제를 바탕으 로 부모가 아동의 덩이짓기 능력을 평가할 수 있는 영역을 구성하 여, 부모 보고 평가를 이용한 $\mathrm{KBPR}$ 이 단순언어장애 아동을 유의 하게 선별할 수 있는지 알아볼 필요가 있다. 추가적으로 본 연구에 서 실시하지 않은 작업기억의 과제들을 사용하여 KBPR과의 연관 성을 살펴봄으로써 KBPR이 언어 능력을 예측할 수 있는 선별검사 도구로 사용되기를 제언한다.

\section{REFERENCES}

Archibald, L. M., \& Joanisse, M. F. (2009). On the sensitivity and specificity of nonword repetition and sentence recall to language and memory impairments in children. Journal of Speech, Language, and Hearing Research, 52(4), 899-914.

Arnon, I., \& Snider, N. (2010). More than words: frequency effects for word phrases. Journal of Memory and Language, 62(1), 67-82.

Baddeley, A. (1986). Working memory. Oxford: Oxford University Press.

Baddeley, A. (1992). Working memory. Science, 255(5044), 556-559.

Baddeley, A., Gathercole, S., \& Papagno, C. (1998). The phonological loop as a language learning device. Psychological Review, 105(1), 158-173.

Baddeley, A., \& Wilson, B. A. (2002). Prose recall and amnesia: Implications for the structure of working memory. Neuropsychologia, 40(10), 1737-1743.

Bannard, C., \& Matthews, D. (2008). Stored word sequences in language learning. Psychological Science, 19(3), 241-248.

Bishop, D. V. M. (1997). Pre- and perinatal hazards and family background in children with specific language impairments a study of twins. Brain Language, 56(1), 1-2.

Bonifacci, P., Mari, R., Gabbianelli, L., Ferraguti, E., Montanari, F., Burani, F., \& Porrelli, M. (2016). Sequential bilingualism and specific language impairment: the Italian version of ALDeQ parental questionnaire. Applied
Psychology Bulletin, 64(275), 50-63.

Casteel, C. A. (1988). Effects of chunked reading among learning disabled students: an experimental comparison of computer and traditional chunked passages. Journal of Educational Technology Systems, 17(2), 115-121.

Cheuck, D. K., \& Wong, V. (2005). Specific language impairment and child care by a domestic helper: a case-control study in Chinese children. Arch Pediatric Adolescent Medicine, 159(8), 714-720.

Cheuck, D. K., Wong, V., \& Leung, G. M. (2005). Multilingual home environment and specific language impairment: a case-control study in Chinese children. Pediatric Perinatal Epidemiology, 19(4), 303-314.

Chiat, S., \& Roy, P. (2007). The Preschool Repetition Test: an evaluation of performance in typically developing and clinically referred children. Journal of Speech, Language, and Hearing Research, 50(2), 429-443.

Cho, S., Park, S., Kwak, E., Kim, K., Min, H., Bae, W., \& Park, H. (2008). Relationship of language, intelligent and aocial quotients in children with speech and language disorder. Journal of the Korean Academy of Rehabilitation Medicine, 32(2), 129-134.

Chun, S., \& Yim, D. (2017). A comparative study of chunking mechanism in children with and without language delay. Communication Sciences \& Disorders, 22(2), 233-244.

Chung, H. J. (2008). Speech and language disorders in children. Korean Journal of Pediatrics, 51(9), 922-934.

Diamond, E., \& Squires, J. (1993). The role of parental report in the screening and assessment of young children. Journal of Early Intervention, 17(2), $107-115$

Dollaghan, C., \& Campbell, T. (1998). Nonword repetition and child language impairment. Journal of Speech, Language, and Hearing Research, 41(5), 11361146.

Ellis, N. C. (1996). Sequencing in SLA: phonological memory, chunking, and points of order. Studies in Second Language Acquisition, 18(1), 91-126.

Ellis, N. C. (2003). Constructions, chunking, and connectionism: the emergence of second language structure. In C. Doughty \& M. H. Long (Eds.), The Handbook of Second Language Acquisition (pp. 63-101). Oxford: Blackwell Publishing Ltd.

Gathercole, S. (2006). Nonword repetition and word learning: the nature of the relationship. Applied Psycholinguistics, 27(4), 513-543.

Gathercole, S. E., \& Baddely, A. D. (1990). Phonological memory deficits in language disordered children: is there a causal connection? Journal of Memory and Language, 29(3), 336-360.

Gathercole, S. E., \& Baddely, A. D. (1993). Phonological working memory: a 
critical building block for reading development and vocabulary acquisition?. European Journal of Psychology of Education, 8(3), 259-272.

Gobet, F., Lane, P. C., Croker, S., Cheng, P. C., Jones, G., Oliver, I., \& Pine, J. M. (2001). Chunking mechanisms in human learning. Trends in Cognitive Sciences, 5(6), 236-243.

Han, J., \& Yim, D. (2018). Korean Brief Parent Report measures of language development in children with vocabulary delay. Journal of Speech-Language \& Hearing Disorders, 27(2), 69-84.

Hong, H., \& Yim, D. (2014). Working memory subsystems and receptive vocabulary in children with specific language impairment. Journal of SpeechLanguage \& Hearing Disorders, 23(2), 35-44.

Hong, Y. (2019). Influence of Chunking Mechanism and Orthographic Fastmapping on Early Literacy Development in Preschool Children. Ewha Womans University, Seoul, Korea.

Hutchinson, E., Bavin, E., Efron, D., \& Sciberras, E. (2012) A comparison of working memory profiles in school-aged children with specific language impairment, attention deficit/hyperactivity disorder, comorbid SLI and ADHD and their typically developing peers. Child Neuropsychology, 18(2), 190-207.

Hwang, M. (2015). Nonword repetition of typically developing children. Communication Sciences and Disorders, 20(3), 374-385.

Janssen, N., \& Barber, H. A. (2012). Phrase frequency effects in language production. PloS ONE, 7(3), e33202.

Jones, G., Gobet, F., Freudenthal, D., Watson, S. E., \& Pine, J. M. (2014). Why computational models are better than verbal theories: the case of nonword repetition. Developmental Science, 17(2), 298-310.

Johnston, J. R., \& Weismer, S. E. (1983). Mental rotation abilities in languagedisordered children. Journal of Speech, Language, and Hearing Research, 26(3), 397-403.

Just, M. A., \& Carpenter, P. A. (1992). A capacity theory of comprehension: individual differences in working memory. Psychological Review, 99(1), 122-149.

Karimijavan, G., Ebadi, A., Yadegari, F., Dastjerdi Kazemi, M., Darouie, A., \& Karimi, S. E. (2019). Sequential bilingualism and language impairment: the Persian version of ALDeQ parental questionnaire. Early Child Development and Care, 191(5), 1-12.

Keenan, J. M., Bailet, S. D., \& Brown, P. (1984). The effects of causal cohesion on comprehension and memory. Journal of Verbal Learning and Verbal Behavior, 23(2), 115-126.

Kim, Y. T., Hong, G. H., Kim, K. H., Jang, H. S., \& Lee, J. Y. (2009). Receptive
\& expressive vocabulary test (REVT). Seoul: Seoul Community Rehabilitation Center.

Kim, Y. T., Seong, T. J., \& Lee, Y. K. (2003). Preschool Receptive-Expressive Language Scale (PRES), Seoul: Seoul Community Rehabilitation Center.

Knight-McKenna, M. (2008). Syllable types: a strategy for reading multisyllabic words. Teaching Exceptional Children, 40(3), 18-24.

Kohnert, K., \& Windsor, J. (2004). The search for common ground. Part II. Nonlinguistic performance by linguistically diverse learners. Journal of Speech, Language, and Hearing Research, 47(4), 891-903.

Lee, E. J., \& Sim, H. S. (2003). Phonological memory in the nonword repetition of children: a comparison of functional phonologically disordered and normal children. Korean Journal of Communication \& Disorders, 8(2), 127-145.

Lee, H. J. (2010). The influences of number of syllables and wordlikeness on 3-to 5-year-old Korean-English bilingual children's nonword repetition (Master's thesis). Ewha Womans University, Seoul, Korea.

Leonard, L. B., Weismer, S. E., Miller, C. A., Francis, D. J., Tomblin, J. B., \& Kail, R. V. (2007). Speed of processing, working memory, and language impairment in children. Journal of Speech, Language, and Hearing Research, 50(2), 408-428.

Mathy, F., \& Feldman, J. (2012). What's magic about magic numbers? Chunking and data compression in short-term memory. Cognition, 122(3), 346362.

May, A., \& Williams, C. (2012). Using parent report for assessment of the first language of English language learners. Journal of Clinical Practice in Speech -Language Pathology, 14(1), 25-30.

Montgomery, J., \& Windsor, J. (2007). Examining the language performances of children with and without specific language impairment: contributions of phonological short-term memory and speed of processing. Journal of Speech, Language, and Hearing Research, 50(3), 778-797.

Moon, S. B., \& Byun, C. J. (2003). Korean Kaufman Assessment Battery for Children (K-ABC). Seoul: Hakjisa.

Nation, I. P. S. (2001). Learning vocabulary in another language. Cambridge: Cambridge University Press.

Oh, D., \& Yim, D. (2013). Non-word repetition and sentence repetition performance in 2-3 years old late talkers and normal children. Communication Sciences \& Disorders, 18(3), 277-287.

Paradis, J., Emmerzael, K., \& Duncan, T. S. (2010). Assessment of English language learners: using parent report on first language development. Journal of Communication Disorders, 43(6), 474-497. 
Polišenská, K., Chiat, S., \& Roy, P. (2015). Sentence repetition: what does the task measure?. International Journal of Language \& Communication Disorders, 50(1), 106-118.

Rönnberg, J., Rudner, M., Foo, C., \& Lunner, T. (2008). Cognition counts: a working memory system for ease of language understanding (ELU). International Journal of Audiology, 47(sup2), S99-S105.

Roy, P., \& Chait, S. (2004). A prosodically controlled word and nonword repetition task for 2-to 4-year olds: evidence from typically developing children. Journal of Speech, Language, and Hearing Research, 47(1), 223-234.

Shriberg, L. D., Lohmeier, H. L., Campbell, T. F., Dollaghan, C. A., Green, J. R., \& Moore, C. A. (2009). A nonword repetition task for speakers with misarticulations: the Syllable Repetition Task (SRT). Journal of Speech, Language, and Hearing Research, 52(5), 1189-1212.

Stark, R. E., \& Blackwell, P. B. (1997). Oral volitional movements in children with language impairments. Child Neuropsychology, 3(2), 81-97.

Stanton-Chapman, T. L., Chapman, D. A., Bainbridge, N. L., \& Scott, K. G. (2002). Identification of early risk factors for language impairment. Research in developmental disabilities, 23(6), 390-405.

Stevens, K. C. (1981). Chunking material as an aid to reading comprehension. Journal of Reading, 25(2), 126-129.

Stokes, S. F., \& Klee, T. (2009). Factors that influence vocabulary development in two-year-old children. Journal of Child Psychology and Psychiatry, 50(4), 498-505.

Tomblin, J. B., Smith, E., \& Zhang, X. (1997). Epidemiology of specific language impairment: prenatal and perinatal risk factors. Journal of Communication Disorders, 30(4), 325-344.
Tuller, L. (2015). Clinical use of parental questionnaires in multilingual contexts. In S. Armon-Lotem, N. Meir, \& J. de Jong (Eds.), Assessing multilingual children: disentangling bilingualism from language impairment (pp. 301-330). Bristol: Multilingual Matters.

Vugs, B., Cuperus, J., Hendriks, M., \& Verhoeven, L. (2013). Visuospatial working memory in specific language impairment: a meta-analysis. $R e$ search in Developmental Disabilities, 34(9), 2586-2597.

Windsor, J., Kohnert, K., Loxtercamp, A. L., \& Kan, P. F. (2008). Performance on nonlinguistic visual tasks by children with language impairment. $A p$ plied Psycholinguistics, 29(2), 237-268.

Yang, Y., Park, S., Hong, Y. E., Lee, S., \& Yim, D. (2019). The phonological similarity pattern of words contributing to expressive vocabulary in 18-to 36-month-old toddlers. Communication Sciences \& Disorders, 24(3), 553564.

Yim, D., \& Han, J. Y. (2019). Phonological loops, visuospatial sketchpad, episodic buffers, and inhibition: the relationship with grammar skills in children with a language delay. Korean Journal of Special Education, 54(2), 183204.

Yim, D. S., Kim, S. Y., \& Yang, Y. H. (2015). Factor analysis of working memory tasks based on information processing characteristics: predictive factors of receptive vocabulary and quick incidental learning in children with typically developing and receptive vocabulary delay. Communication Sciences \& Disorders, 20(2), 304-318.

Yim, D. S., Yang, Y. H., \& Kim, S. Y. (2015). Domain-specific working memory performance in children with and without specific language impairment. Communication Sciences \& Disorders, 20(1), 13-23. 
Appendix 1. Examples of Korean word list recall

\begin{tabular}{|c|c|c|c|}
\hline 아동명(성별) & 생년월일(CA) & \\
\hline 검사자 & 검사일 & \\
\hline
\end{tabular}

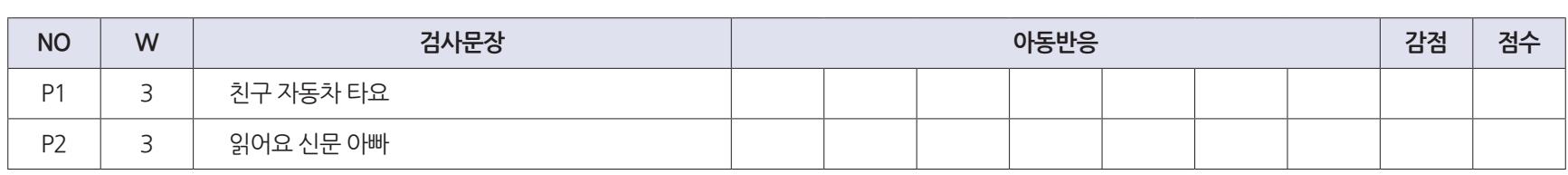

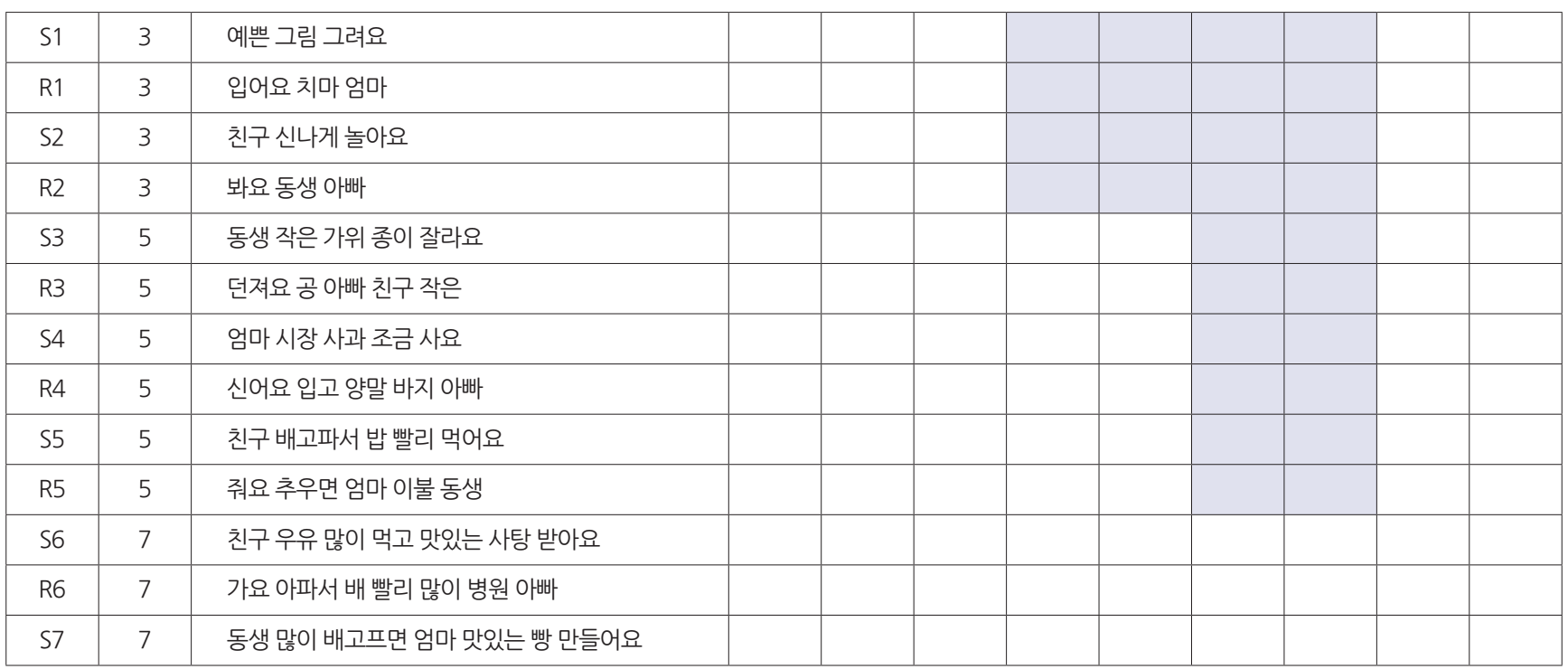

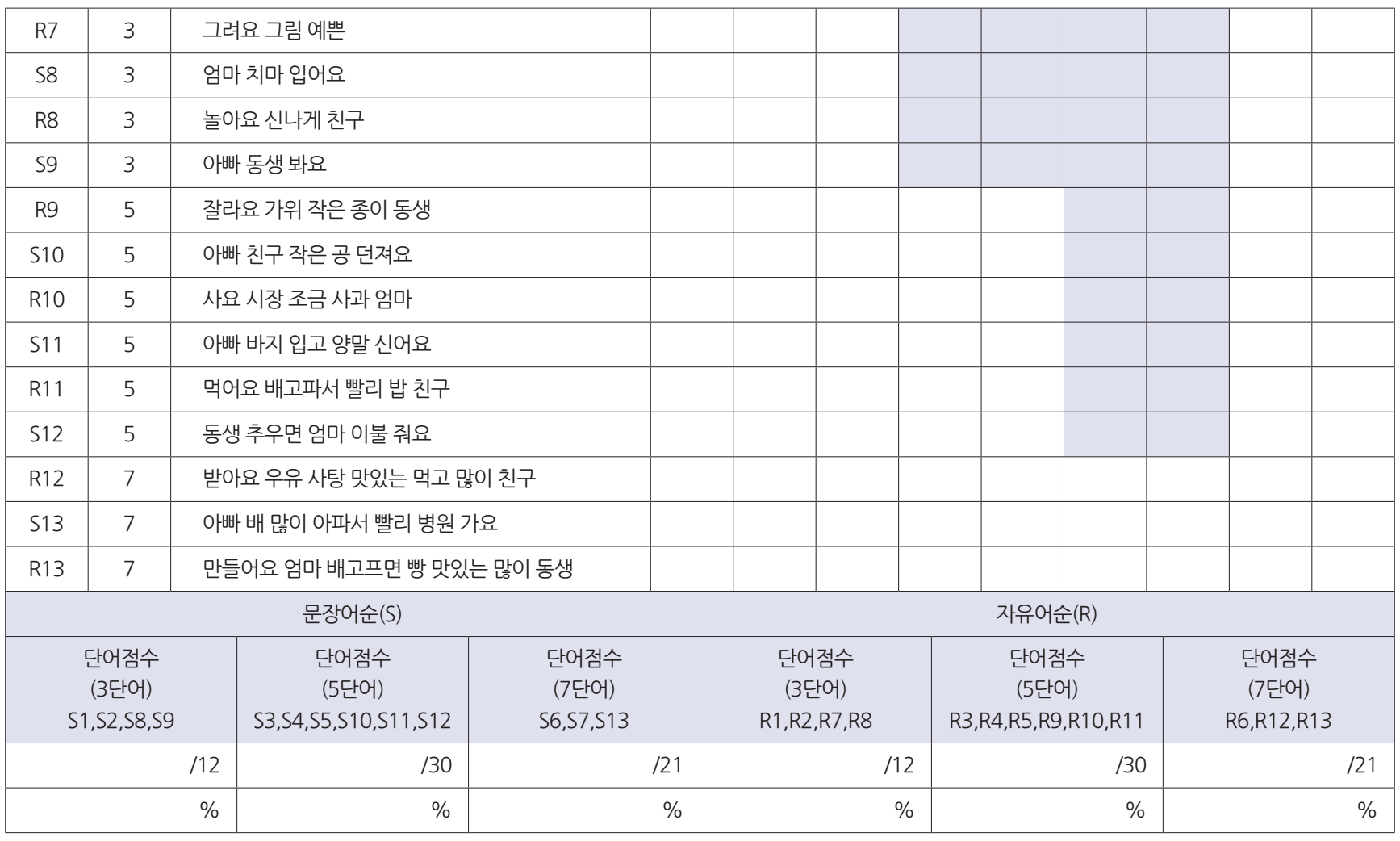


Appendix 2. Examples of Korean Brief Parent Report: KBPR

\begin{tabular}{|l|r|l|l|}
\hline 아동이름 (성별) & (남 / 여) & 아동의 생년월일 & \\
\hline 작성자이름 & & 아동과의 관계 & \\
\hline 아동의 주 양육자 & & 작성일 & \\
\hline
\end{tabular}

\begin{tabular}{|c|c|}
\hline A. 초기 이정표 & \\
\hline 1. 당신의 아동은 언제 '걷기’를 시작하였나요? & $\begin{array}{l}\text { 3점 }=\langle 15 \text { 개월 } \\
\text { 0점 }=>16 \text { 개월 } \\
\text { 점수: } \quad \text { /3점 }\end{array}$ \\
\hline 2. 당신의 아동은 언제 ‘첫 낱말’을 시작하였나요? & $\begin{array}{l}\text { 6점 }=\langle 15 \text { 개월 } \\
\text { 4점 }=16-24 \text { 개월 } \\
\text { 0점 }=>25 \text { 개월 } \\
\text { 점수: } \quad \text { /6점 }\end{array}$ \\
\hline $\begin{array}{l}\text { 3. 당신의 아동은 언제 ‘낱말을 나열하거나', “짧은 문장을 사용하여 말하기 시작하였나요? } \\
\text { 예) 짧은 문장: } 2 \text { 개 이상의 단어, “엄마, 우유” } \\
\text { *아동이 발화하였던 문장을 예를 들어 적어주세요. } \\
\text { ( }\end{array}$ & $\begin{array}{l}\text { 6점 }=\langle 24 \text { 개월 } \\
\text { 4점 }=25-30 \text { 개월 } \\
\text { 0점 }=>31 \text { 개월 } \\
\text { 점수: } \quad \text { /6점 }\end{array}$ \\
\hline 4. 당신의 아동이 말을 하기 시작하였을 때, 또래 아동에 비교하였을 때 다른 점이 있다면, 무엇인가요? & $\begin{array}{l}\text { 6점 }=\langle 24 \text { 개월 } \\
\text { 4점 }=25-30 \text { 개월 } \\
\text { 0점 }=>31 \text { 개월 } \\
\text { 점수: } \quad \text { /6점 }\end{array}$ \\
\hline 총점 & _ / 18점 \\
\hline
\end{tabular}

\begin{tabular}{|c|c|}
\hline B. 현재 언어 능력 & \\
\hline 5. 또래아동과 비교하였을 때, 아동이 자신의 의사를 표현하는 것에 대해 어떻게 생각하나요? & $\begin{array}{l}\text { 0점 = 잘하지 못한다 } \\
\text { 1점 = 조금 덜 잘한다 } \\
\text { 2점 =또래아동과 같다 } \\
\text { 3점 = 매우 잘한다 } \\
\text { 점수:_ / 3점 }\end{array}$ \\
\hline 6. 또래아동과 비교하였을 때, 아동이 단어를 발음하는 것에 대해 어떻게 생각하나요? & $\begin{array}{l}\text { 0점 }=\text { 불명확하다 } \\
\text { 1점 }=\text { 가끔 불명확하다 } \\
\text { 2점 =또래아동과 같다 } \\
\text { 3점=매우 명확하다 } \\
\text { 점수:_/3점 }\end{array}$ \\
\hline 7. 당신의 가족 또는 친구들은 아동과 대화하는 것을 쉽게 생각하는 편입니까? & $\begin{array}{l}\text { 3점 }=\text { 매우 쉽다 } \\
\text { 2점=충분히 쉽다 } \\
\text { 1점=가끔 쉽지 않다 } \\
\text { 0점=매우 어렵다 } \\
\text { 점수:_ / 점 }\end{array}$ \\
\hline $\begin{array}{l}\text { 8. 또래아동과 비교하였을 때, 당신의 아동은 올바른 문장을 산출하는 것에 어려움이 있습니까? } \\
\text { (예: 정확한 어휘, 올바른 문법, 자신의 생각을 전달하기 위해 충분히 긴 문장의 사용을 어려워한다.) }\end{array}$ & $\begin{array}{l}\text { 3점 }=\text { 어렵지 않다 } \\
\text { 2점 }=\text { 또래아동과 같다 } \\
\text { 1점 }=\text { 가끔 어렵다 } \\
\text { 0점 }=\text { 매우 어렵다 } \\
\text { 점수:_ / } 3 \text { 점 }\end{array}$ \\
\hline 9. 당신 아동의 언어 능력(한국어 사용)에 만족하나요? & $\begin{array}{l}\text { 3점 }=\text { 완전히 만족한다 } \\
\text { 2점 }=\text { 만족한다 } \\
\text { 1점 }=\text { 만족하지 못한다 } \\
\text { 0점 =전혀 만족하지 못한다 } \\
\text { 점수:_ / 3점 }\end{array}$ \\
\hline 총점 & _ / 15점 \\
\hline
\end{tabular}




\begin{tabular}{|c|c|}
\hline \multicolumn{2}{|l|}{ C. 행동 패턴 및 활동 선호도 } \\
\hline 10. 당신의 아동은 책을 읽거나 성인이 책 읽어주는 것을 좋아하나요? & $\begin{array}{l}0 \text { 점 }=\text { 전혀 좋아하지 않는다 } \\
\text { 1점 }=\text { 드물게 좋아한다 } \\
\text { 2점 }=\text { 가끔 좋아한다 } \\
\text { 3점 }=\text { 매우 좋아한다 } \\
\text { 점수:_ } \quad / 3 \text { 점 }\end{array}$ \\
\hline 11. 또래아동과 비교하였을 때, 아동의 읽기쓰기 능력은 어떠한가요? & $\begin{array}{l}\text { 0점 }=\text { 눈에 띄게 나쁘다 } \\
\text { 1점 }=\text { 또래보다 낫지 않다 } \\
\text { 2점 = 또래아동과 같다 } \\
\text { 3점 = 매우 잘한다 } \\
\text { 점수: } \quad \text { / 3점 }\end{array}$ \\
\hline 12. 아동이 선호하는 활동은 무엇인가요? & $\begin{array}{l}\text { 3점 }=\text { 언어놀이 (예: 독서, 쓰기 등) } \\
\text { 2점= 인지놀이 (예: 퍼즐, 그림, 컴퓨터게임 등) } \\
\text { 1점=신체놀이 (예: 축구, 농구, 수영) } \\
\text { 0점 = 기타 (예: TV, 비디오게임, 유아놀이 등) } \\
\text { 점수: ㄷㅈ점 }\end{array}$ \\
\hline $\begin{array}{l}\text { 13. 당신의 아동은 새로운 것을 학습할 때 얼마나 빠르고, 쉽게 배우나요? } \\
\text { (예: 스포츠, 단어, 게임, 퍼즐, 새로운 장난감) } \\
\text { 아동이 새로운 것을 학습하는 것의 예를 들어주세요. } \\
\text { ( }\end{array}$ & $\begin{array}{l}\text { 3점 }=\text { 같은 날 / 즉시 } \\
\text { 2점 }=\text { 몇 번의 시도 } \\
\text { 1점 }=\text { 학습을 위한 시간과 도움 필요 } \\
\text { 0점 }=\text { 오랜 시간 / 때때로 학습의 어려움 } \\
\text { 점수:__ / 3점 }\end{array}$ \\
\hline $\begin{array}{l}\text { 14. 당신의 아동에게 보이는 활동의 패턴은 무엇인가요? } \\
\text { (예: 게임, 식사, TV 시청, 신체놀이, 음악, 춤 등) }\end{array}$ & $\begin{array}{l}\text { 3점 }=\text { 한번에 } 1 \text { 개의 활동과 마무리 } \\
\text { 2점 }=1-2 \text { 개의 활동과 마무리 } \\
\text { 1점 }=2-4 \text { 개의 활동과 마무리 } \\
\text { 0점 }=\text { 그 이상의 활동, 그리고 하나의 활동을 } \\
\text { 마무리하는 것조차도 어려워함 } \\
\text { 점수: } \quad \text { / 3점 }\end{array}$ \\
\hline 15. 당신의 아동은 자신의 생각을 전달하지 못해 좌절한 적이 있습니까? & $\begin{array}{l}\text { 3점 }=\text { 없다 } \\
\text { 2점 }=\text { 가끔 } \\
\text { 1점 }=\text { 종종 } \\
\text { 0점 }=\text { 빈번 } \quad \text { /3점 } \\
\text { 점수: }\end{array}$ \\
\hline 총점 & / \\
\hline
\end{tabular}

\begin{tabular}{|c|c|c|c|c|c|c|}
\hline \multicolumn{6}{|l|}{ D. 가족력 } & \\
\hline \multicolumn{6}{|c|}{$\begin{array}{l}\text { 16. 가족 구성원이 모두 고등학교를 졸업했습니까? 그렇지 않다면, 이유를 적어주세요. } \\
\text { ( }\end{array}$} & $\begin{array}{l}\text { 3점 }=\text { 네 } \\
\text { 0점 }=\text { 아니오 } \\
\text { 점수: /3점 }\end{array}$ \\
\hline \multicolumn{6}{|c|}{$\begin{array}{l}\text { 17. 직계가족이나 친척 중에서 다음과 같은 문제를 보이는 가족이 있나요? } \\
\text { *가족력이 있다면, 아래의 표에 표시해주세요. }\end{array}$} & \multirow{10}{*}{$\begin{array}{l}\text { 6점 }=\text { 없다 } \\
\text { 3점 }=\text { 가능성이 있다 } \\
\text { 0점 }=\text { 확실히 있다 } \\
\text { 점수:_ / 점 }\end{array}$} \\
\hline & 형제자매 & 아버지 & 어머니 & 아버지 친척 & 어머니 친척 & \\
\hline \multicolumn{6}{|c|}{ 학교 또는 학습의 어려움 } & \\
\hline \multicolumn{6}{|l|}{ 언어 또는 발음 문제 } & \\
\hline \multicolumn{6}{|l|}{ 특수교육 } & \\
\hline \multicolumn{6}{|l|}{ 말, 언어치료 } & \\
\hline \multicolumn{6}{|c|}{ 지시따르기 또는 질문 이해 문제 } & \\
\hline \multicolumn{6}{|c|}{ 읽기 또는 읽기학습의 문제 } & \\
\hline \multicolumn{6}{|l|}{ 영어 학습 어려움 } & \\
\hline 학교 안에서의 유급 & & & & & & \\
\hline
\end{tabular}




\section{국문초록}

\section{단순언어장애 아동과 일반 아동의 KBPR (Korean Brief Parent Report)과 작업기억 능력 간의 관계: 음운루프, 일화적 완충기를 중심으로}

임동선 ${ }^{1} \cdot$ 신현지 ${ }^{1}$ - 임나은 ${ }^{1}$ 정예영 ${ }^{1}$ · 한지민 ${ }^{1} \cdot$ 양윤희 ${ }^{2}$

${ }^{1}$ 이화여자대학교 대학원 언어병리학과, ${ }^{2}$ 이화여자대학교 특수교육연구소

배경 및 목적: Korean Brief Parent Report (KBPR)과 작업기억(음운루프, 언어 및 비언어적 일화적 완충기)의 상관관계와아동의 언어 능력을 유의하게 예측할 수 있는 과제를 알아보고자 한다. 방법: 51-80개월(평균 63개월) 학령전기 단순언어장애 아동 21명, 일반 아동 31 명을 대상으로 KBPR과 작업기억 과제(비단어 따라말하기, 단어목록회상, 대칭-비대칭 매트릭스)를 실시하였다. 결과: 첫째, 집단 간 KBPR 영역별 점수 및 총 점수에서 (b) 현재 언어 수준, (c) 행동 패턴 및 활동 선호도, 총 점수에서 집단 간 유의한 차이를 보였다. 둘째, 음운루프, 언어적 일화적 완충기에서 집단 간 유의한 차이가 있었다. 셋째, 집단 간 $\mathrm{KBPR}$ 의 각 영역 점수 결과와 작업기억 간 상관관계 는 일반 아동 집단에서 언어적 일화적 완충기(문장어순)이 (a) 영역을 제외하고 일관되게 나타났으며, 단순언어장애 아동 집단에서는 (a) 영역은 음운루프, (b) 영역은 언어적 일화적 완충기(문장어순), (c) 영역은 비언어적 일화적 완충기(대칭, 비대칭)와 유의한 상관관계 를 보였다. 넷째, KBPR 총 점수에 가장 유의한 예측요인은 일반 아동 집단은 언어적 일화적 완충기(문장어순), 단순언어장애 아동 집단 은 음운루프였다. 논의 및 결론: 두 집단의 KBPR 점수 및 작업기억 과제는 영역별 유의한 차이를 보였다. 또한, 각 집단 간 KBPR 총 점 수를 가장 유의하게 예측할 수 있는 요인으로 단순언어장애 아동 집단은 음운루프, 일반 아동 집단은 언어적 일화적 완충기(문장어순) 였다.

핵심어: 부모 보고, 부모 설문지, 음운루프, 일화적 완충기, 작업기억

본 연구는 2020년 대한민국 과학기술정보통신부와 한국연구재단의 지원을 받아 수행된 연구임(NRF-2019R1A2C1007488).

\section{참고문헌}

김영태, 성태제, 이윤경 (2003). 취학 전 아동의 수용언어 및 표현언어 발달척도(Preschool Receptive Expressive Language Scale, PRES). 서울: 서울 장애인종합복지관.

김영태, 홍경훈, 김경희, 장혜성, 이주연 (2009). 수용·표현어휘력검사(Receptive \& Expressive Vocabulary Test, REVT). 서울: 서울장애인복지관. 문수백, 변창진 (2003). 한국 카우프만 아동용 지능검사. 서울: 학지사.

오다연, 임동선 (2013). 2-3세 말 늦은 아동과 정상 아동의 비단어따라말하기와 문장 따라말하기 수행 능력. Communication Sciences \& Disorders, 18(3), 277-287.

양윤희, 박수연, 홍예은, 이수연, 임동선 (2019). 18-36개월 유아의 표현어휘력에 기여하는 단어의 음운유사도 양상. Communication Sciences \& Disorders, 24(3), 553-564.

이은주, 심현섭 (2003). 무의미 음절 따라말하기를 통한 단순조음음운장애 아동과 정상아동의 음운기억 수행능력 비교연구. 언어청각장애연구, 8(2), 127-145.

이현정 (2010). 음절길이와 단어유사성이 3-5세 한국어-영어 이중언어아동의 비단어 따라말하기 수행에 미치는 영향. 이화여자대학교 대학원 박사 학위논문.

임동선, 김신영, 양윤희 (2015). 정보처리 특성에 따른 작업기억 과제의 탐색적 요인분석. Communication Sciences \& Disorders, 20(2), 304-318.

임동선, 양윤희, 김신영 (2015). 단순언어장애 아동과 일반 아동의 작업기억 제시방식 및 과제유형에 따른 수행능력 비교. Communication Sciences

\& Disorders, 20(1), 13-23.

임동선, 한지윤 (2019). 언어발달지체 아동의 음운루프, 시 · 공간 잡기장, 일화적 완충기, 억제기능과 문법 능력 간의 관계. 특수교육학연구, $54(2), 183-$ 
204.

정희정 (2008). 소아에서 말 언어장애. Korean Journal of Pediatrics, 51(9), 922-934.

조성래, 박은숙, 박창일, 곽은희, 김미경, 민경훈, 배병우, 박진희 (2008). 말·언어 장애 아동에서 언어지수와 지능 및 사회지수의 관계. 대한재활의학회

지, 32(2), 129-134

천소연, 임동선 (2017). 단어목록 회상을 통한 언어발달지체 아동과 일반아동의 덩이짓기 능력 연구. Communication Sciences \& Disorders, 22(2),

223-244.

홍예은 (2019). 미취학 아동의 초기문해력에 덩이짓기와 빠른문자연결 능력이 미치는 영향. 이화여자대학교 대학원 석사학위논문.

홍현주, 임동선 (2014). 단순언어장애 아동의 작업기억 하위체계와수용어휘능력 간의 관계. 언어치료연구, 23(2), 35-44.

한지윤, 임동선 (2018). 부모 보고형 아동 언어 능력 평가도구(KBPR)의 표준화를 위한 예비연구. 언어치료연구, 27(2), 69-84.

황민아 (2015). 일반 아동의 비단어 따라말하기. Communication Sciences \& Disorders, 20(3), 374-385.

\section{ORCID}

임동선(제1저자, 교신저자, 교수 https://orcid.org/0000-0001-8254-9504); 신현지(공동저자, 대학원생 https://orcid.org/0000-0003-4527-3013); 임나은(공동저자, 대학원생 https://orcid.org/0000-0002-1472-2595); 정예영(공동저자, 대학원생 https://orcid.org/0000-0001-9560-7822); 한지민(공동저자, 대학원생 https://orcid.org/0000-0002-1882-584X); 양윤희(공동저자, 박사후연구원 https://orcid.org/0000-0003-3240-5996) 